\title{
Kualitas Air dan Komunitas Plankton Pada Tambak Pesisir Kabupaten Subang Jawa Barat
}

\author{
(Water Quality And Pond In Coastal Communities Plankton Subang Regency West Java)
}

Oleh: Dinno Sudinno ${ }^{\bowtie}$, Iis Jubaedah, Pigoselpi Anas

Sekolah Tinggi Perikanan, Jurusan Penyuluhan Perikanan

Jalan Cikaret Nomor 1 Bogor 16001, Jawa Barat

Diterima: 27 Februari 2015; Disetujui: 9 Juni 2015

\begin{abstract}
Abstrak
Kabupaten Subang merupakan salah satu wilayah pesisir dengan luas 333,57 km2 atau sekitar 16\% dari luas seluruh Kabupaten Subang, memiliki hutan mangrove dan sangat potensial untuk pengembangan usaha budidaya. Telah dilakukan penelitian di tambak silvofishery kawasan pesisir Kabupaten Subang pada bulan Mei sampai dengan Agustus 2014. Tujuan penelitian untuk mengetahui bagaimana Kualitas air pada Tambak Silvofishery dan bagaimana komunitas plankton pada Tambak Silvofishery Pesisir Kabupaten Subang Jawa Barat. Metode yang digunakan dalam penelitian ini adalah metode survei. Pengamatan dilakukan pada 6 (Enam) stasiun pengamatan di Kecamatan Blanakan. Analisa Data terdiri dari analisis kualitas air dan indeks diversitas plankton. Hasil penelitian menunjukan Parameter kualitas air suhu, salinitas, pH, kecerahan, TSS, NO2, NO3, PO4, DO, BOD dan COD nilainya di semua stasiun memenuhi nilai baku mutunya masing-masing. Sedangkan parameter NH3 dan NO3 di semua stasiun telah melebihi nilai baku mutunya masing masing. Komunitas plankton pada 6 (enam) stasiun pengambilan contoh di tambak Subang mendapatkan data plankton secara keseluruhan berjumlah 13 jenis, terdiri dari 10 jenis fitoplankton dan 3 jenis zooplankton. Pada masing-masing stasiun menunjukkan bahwa jumlah taksa berkisar antara 6 hingga 13 jenis, dengan kelimpahan total berkisar antara 400 hingga 2020 individu/liter. Hasil penghitungan indeks diversitas menunjukkan bahwa tingkat keanekaragaman komunitas plankton pada tambak yang bermangrove secara keseluruhan tergolong rendah yakni dari 1,2299 sampai 1,2731. Sedangkan pada tambak yang tidak bermangrove secara keseluruhan tergolong sangat rendah yakni dari 0,3509 sampai 0,7374. dan Fitoplankton yang mendominasi adalah divisi Chrysophyta.
\end{abstract}

Kata kunci: kualitas air,plankton, silvofishery, tambak, kabupaten subang

\begin{abstract}
Subang Regency is one of the coastal region with an area of $333.57 \mathrm{~km} 2$, or approximately $16 \%$ of total area of Subang Regency, has mangrove forests and great potential for the development of the cultivation. research was conduct on pond Silvofishery coastal area of Subang district in May to August 2014. The research aimed to find out how the water quality in ponds Silvofishery and how plankton communities in the Coastal Embankment Silvofishery Subang regency, West Java. The method used in this study is a survey method. Observations were made on 6 (Six) observation stations in the District Blanakan. Data analysis consisted of analysis of water quality and plankton diversity index. The results showed the water quality parameters of temperature, salinity, $\mathrm{pH}$, brightness, TSS, NO2, NO3, PO4, DO, BOD and COD values in all the stations meets the quality standard value respectively. While the parameters NH-3 and NO3 at all stations have exceeded the quality standard values, respectively. Plankton communities in 6 (six) sampling station in Subang pond plankton get the data as a whole amounted to 13 species, consisting of 10 types of phytoplankton and zooplankton 3 types. At each station shows that the number of taxa ranged from 6 to 13 species, with an abundance of total ranging between 400 and 2020 individuals / liter. Diversity index calculations showed that the plankton community diversity on farms mangrove overall is relatively low, ie from 1.2299 to 1.2731 . While the pond is not bermangrove overall considered very low ie from 0.3509 to 0.7374 . and Phytoplankton is dominated division Chrysophyta.
\end{abstract}

Keyword : water quality, plankton, silvofishery, pond, subang regency

$\triangle$ Penulis korespondensi

Alamat surel: 16.dinno@gmail.com 


\section{Pendahuluan}

Latar Belakang

Wilayah pantai dan pesisir memiliki arti yang strategis karena merupakan wilayah interaksi/peralihan (interface) antara ekosistem darat dan laut yang memiliki sifat dan ciri yang unik, dan mengandung produksi biologi cukup besar serta jasa lingkungan lainnya. Wilayah pesisir merupakan ekosistem transisi yang dipengaruhi daratan dan lautan, yang mencakup beberapa ekosistem, Salah satu bentuk keterkaitan antara ekosistem di wilayah pesisir dapat dilihat dari pergerakan air sungai, aliran limpasan (run-off), aliran air tanah (ground water) dengan berbagai materi yang terkandung didalamnya (nutrien, sedimentasi, dan bahan pencemar) yang kesemuanya akan bermuara ke perairan pesisir. Selain itu, pola pergerakan massa air ini juga akan berperan dalam perpindahan biota perairan (plankton,ikan, udang) dan bahan pencemar dari satu lokasi ke lokasi lainnya (Bengen,2000).

Salah satu ekosistem wilayah pesisir adalah hutan mangrove. Hutan mangrove merupakan ekosistem utama pendukung kehidupan penting di wilayah pesisir dan kelautan. Selain mempunyai fungsi ekologis sebagai penyedia nutrien bagi biota perairan, tempat pemijahan dan asuhan (nursery ground) berbagai macam biota, penahan abrasi pantai, penyerap limbah dan pencegah interusi air laut, Kawasan hutan mangrove yang memiliki nilai ekologi dan ekonomi yang tinggi terus menerus mengalami degradasi akibat dikonversi dan berubah fungsi untuk kegiatan lainnya, seperti pemukiman, pariwisata, perhubungan, reklamasi pantai, budidaya perikanan dan sebagainya. Disinyalir bahwa konversi lahan mangrove untuk pemukiman dan tambak udang merupakan salah satu faktor penyebab kerusakan yang cukup besar. Untuk melindungi kawasan mangrove dari kerusakan lebih lanjut, salah satu konsep pengembangan yang dapat mengkombinasikan antara pemanfaatan dan sekaligus konservasi di kawasan mangrove adalah silvo-fishery

Hutan mangrove merupakan sumber daya alam daerah tropis yang mempunyai manfaat ganda baik dari aspek sosial ekonomi maupun ekologi. Besarnya peranan ekosistem hutan mangrove bagi kehidupan dapat diketahui dari banyaknya jenis hewan baik yang hidup di perairan, di atas lahan maupun di tajuk- tajuk pohon mangrove atau manusia yang bergantung pada hutan mangrove tersebut (Naamin, 1991).

Hutan mangrove merupalan ekosistem hutan yang khas terutama karena posisinya sebagai peralihan antara ekosistem darat dan ekosistem taut. Kondisi lingkungan fisiknya yang sangat khusus menyebabkan ekosistem mangrove memiliki keanekaragaman hayati yang terbatas dan ekosistem ini sangat rentan terhadap adanya pengaruh luar terutama karena species biota pada hutan mangrove memiliki toleransi yang sempit terhadap adanya perubahan dari luar. pengelolaan kawasan mangrove melalui wanamina maka didapat beberapa manfaat secara ekologi dan ekonomi (Nuryanto, 2003), yaitu:

a. Menjamin keberadaan ekosistem hutan mangrove dengan luasan yang cukup dan sebaran yang proporsional.

b. Mengoptimalkan aneka fungsi kawasan tersebut, termasuk fungsi konservasi, fungsi lindung dan fungsi produksi untuk mencapai manfaat lingkungan, sosial dan ekonomi yang seimbang secara berkelanjutan.

c. Meningkatkan daya dukung kawasan.

Mendukung pengembangan kapasitas dan keberdayaan masyarakat secara partisipatif, berkeadilan dan berwawasan lingkungan sehingga menciptakan ketahanan sosial ekonomi

Jurnal Penyuluhan Perikanan dan Kelautan 


\section{Rumusan Masalah}

Berdasarkan hal-hal di atas, rumusan masalah adalah sebagai berikut:

a. Bagaimana Kualitas air pada Tambak Silvofishery Pesisir Kabupaten Subang Jawa Barat.

b. Bagaimana Komunitas plankton pada Tambak Silvofishery Pesisir Kabupaten Subang Jawa Barat.

Tujuan penelitian

Tujuan penelitian ini adalah untuk :

a. Mengetahui Kualitas air pada Tambak Silvofishery Pesisir Kabupaten Subang Jawa Barat.

b. MengetahuiKomunitas plankton pada Tambak SilvofisheryPesisir Kabupaten Subang Jawa Barat.

\section{Metode Penelitian}

Tempat dan Waktu Penelitian

Penelitian dilakukan di tambak silvofishery kawasan Pesisir Kabupaten Subang pada bulan Mei sampai dengan Agustus 2014. Pengamatan dilakukan di 6 stasiun pengamatan seperti terlihat pada gambar 1 dan tabel 1 .

\section{Metoda Penelitian}

Metode yang digunakan dalam penelitian ini adalah metode survei.

Pengumpulan data

Data yang digunakan dalam penelitian ini adalah data primer dan data sekunder. Data primer diperoleh melalui survei langsung di lapangan yaitu terhadap :

\section{Kualitas Air}

Untuk mendapatkan data kualitas air dilakukan pengukuran parameter fisika dan kimia langsung dilapangan maupun mengambil sampel air untuk diuji dilaboratorium. Jenis parameter fisika dan kimia yang diukur meliputi suhu, salinitas, $\mathrm{pH}$, kecerahan, TSS, $\mathrm{NH}_{3}, \mathrm{No}_{2}, \mathrm{No}_{3}, \mathrm{Po}_{4}$, Oksigen terlarut, BOD dan COD.

\section{Fitoplankton}

Untuk mendapatkan contoh plankton, air sebanyak kurang lebih 50 liter disaring menggunakan plankton net No 25 menjadi $50 \mathrm{ml}$ dan diawetkan dengan lugol atau formalin. Identifikasi jenis dilakukan di laboratorium menggunakan mikroskop dan buku identifikasi.

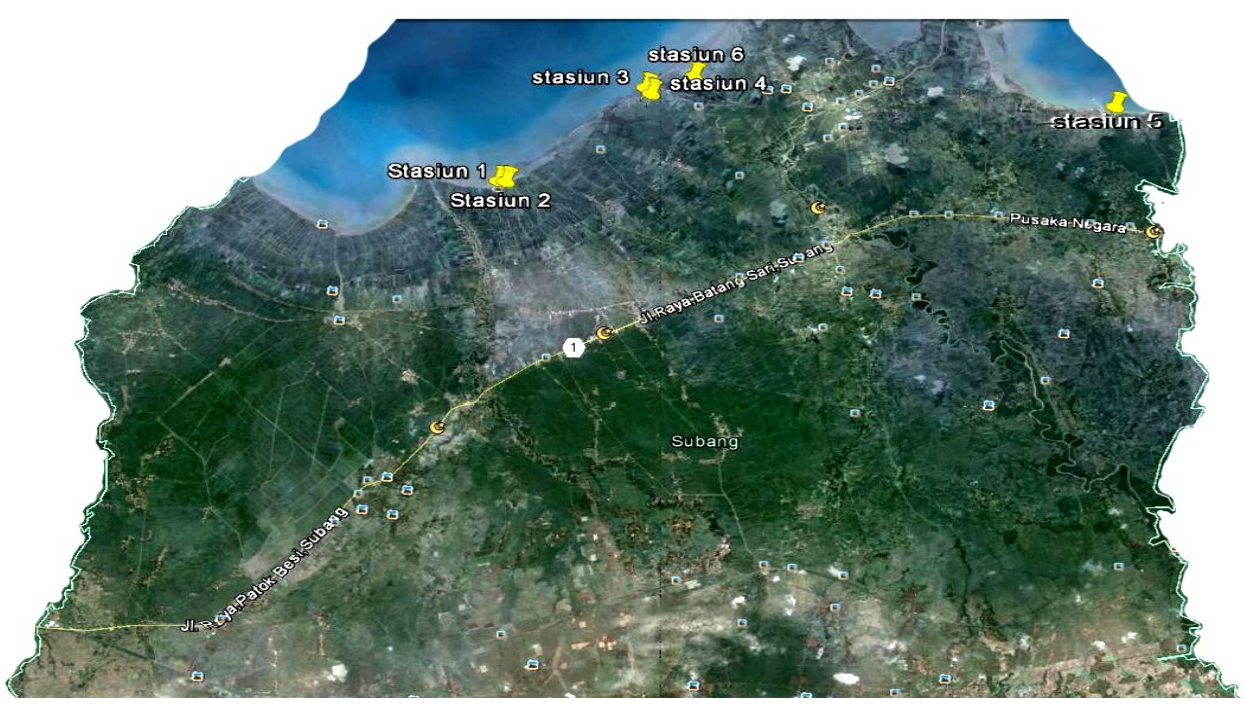

Gambar 1. Peta lokasi penelitian 
Tabel 1. Stasiun pengamatan penelitian di Pesisir Kabupaten Subang

\begin{tabular}{|c|c|c|c|}
\hline No. st & Kecamatan & Lokasi pengamatan & Keterangan \\
\hline 1. & Blanakan & $6^{\circ} 14^{\prime} 26,84^{\prime \prime} \mathrm{S}-107^{\circ} 43^{\prime} 18,45^{\prime \prime}$ & $\begin{array}{l}\text { Mangrove tebal }(40 \%) \text { di tengah } \\
\text { tambak }\end{array}$ \\
\hline 2 . & Blanakan & $6^{\circ} 14^{2} 22,08^{\prime \prime} \mathrm{S}-107^{\circ} 43^{\prime} 8,86^{\prime \prime}$ & Tanpa mangrove di tambak \\
\hline 3. & Pamanukan & $6^{\circ} 12^{\prime} 45,19^{\prime \prime} \mathrm{S}-107^{\circ} 46^{\prime} 25,77^{11}$ & Tanpa mangrove di tambak \\
\hline 4. & Pamanukan & $6^{\circ} 12^{\circ} 55,59^{\prime \prime} \mathrm{S}-107^{\circ} 46^{\circ} 30,02^{\prime \prime}$ & Mangrove hanya $(20 \%)$ di pematang \\
\hline 5. & Pusakanegara & $6^{\circ} 15^{\prime} 16,4^{\prime \prime} \mathrm{S}-107^{\circ} 55^{\prime} 17,17^{\prime \prime \prime}$ & $\begin{array}{l}\text { Mangrove Tipis }(10 \%) \text { di tengah } \\
\text { tambak }\end{array}$ \\
\hline 6. & Legon Kulon & 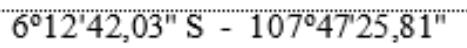 & Tanpa mangrove di tambak \\
\hline
\end{tabular}

\section{Analisa Data}

Kualitas Air

Jenis dan cara pengukuran parameter físika dan kimia terlihat pada Tabel 2.

Indeks Diversitas Plankton

Analisa terhadap plankton dilakukan dengan menghitung nilai indeks diversitas dari plankton dengan Shannon Wieners formula (Soegianto, 2004) :

$\mathbf{H}=-\sum \mathbf{n}_{\mathbf{i}} / \mathbf{N} \ln \mathbf{n}_{\mathbf{i}} / \mathbf{N}$

Shannon dan Wieners dalam Poole (1974) menyatakan bahwa berdasarkan indeks diversitas $\left(\mathrm{H}^{\prime}\right)$, kualitas air dikelompokkan atas 5 kategori seperti yang terdapat pada Tabel 3.

\section{Hasil dan Pembahasan}

Luas Kabupaten Subang 205.176,95 Ha (4,64\% dari luas Jawa Barat) dengan ketinggian antara 0-1500 mdpl. Dilihat dari segi topografinya dapat dibedakan menjadi 3 zone daerah yaitu : Daerah pegunungan dengan ketinggian 500-1500 mdpl dengan luas 41.035,09 На (20\%), daerah berbukit dengan ketinggian 50-500 mdpl dengan luas 71.502,16 Ha (35\%), daerah dataran rendah dengan ketinggian 0-50 mdpl dengan luas 92.939,7 На (45\%). Sekitar 80,8\% Kabupaten Subang kemiringan $0-17^{\circ}$, sedangkan sisanya memiliki kemiringan diatas $18^{\circ}$. Secara umum Kabupaten Subang beriklim tropis dengan curah hujan ratarata pertahun $1593 \mathrm{~mm}$.

Tabel 2. Parameter dan Cara Analisis Kualitas Air

\begin{tabular}{|c|c|c|c|c|}
\hline No & Parameter & Satuan & Alat/Cara Analisis & Keterangan \\
\hline A. & Fisika & & & \\
\hline 1 . & Kecerahan & $\mathrm{cm}$ & Secchi disk & In situ \\
\hline 2 . & Suhu & ${ }^{\circ} \mathrm{C}$ & Thermometer & In situ \\
\hline 3. & (TSS) & $\mathrm{mg} /$ & Gravimetri & Laboratorium \\
\hline B. & Kimia & & & \\
\hline 4. & $\mathrm{pH}$ & $=$ & $\mathrm{pH}$ meter & In situ \\
\hline 5. & Salinitas & $\%$ & Refraktometer & In situ \\
\hline 6. & Oksigen terlarut & $\mathrm{Mg} / \mathrm{I}$ & DO meter & In situ \\
\hline 7 . & BOD & $\mathrm{mg} / 1$ & Botol sample; Titrimetrik & Laboratorium \\
\hline 8. & $\mathrm{COD}$ & $\mathrm{mg} / 1$ & Botol sample; Titrimetrik & Laboratorium \\
\hline 9 & Ammonia & $\mathrm{mg} /$ & Botol sample; Titrimetrik & Laboratorium \\
\hline 10 & Nitrat & $\mathrm{mg} / \mathrm{I}^{-1}$ & Botol sample ; Titrimetrik & Laboratorium \\
\hline 11 & Nitrit & $\mathrm{mg} / 1$ & Botol sample ; Titrimetrik & Laboratorium \\
\hline 12 & Phospat & $\mathrm{mg} / 1$ & Botol sampel; Titrimetrik & Laboratorium \\
\hline
\end{tabular}


Tabel 3. Kriteria kualitas air berdasarkan indeks diversitas ( $\left.\mathrm{H}^{\prime}\right)$

\begin{tabular}{|l|l|}
\hline Indeks Diversitas & Kriteria kualitas air \\
\hline$<1,00$ & Sangat rendah (tercemar berat) \\
\hline $1,00-1,66$ & Rendah \\
\hline $1,67-2,33$ & Sedang \\
\hline $2,34-3,00$ & Baik \\
\hline$>3,00$ & Sangat baik (tidak tercemar) \\
\hline
\end{tabular}

Sumber: Shannon dan Weiners dalam Poole (1974)

Dari 20 kecamatan hanya 4 kecamatan yang merupakan kecamatan pesisir dapat dilihat pada Tabel 4.Luas wilayah kecamatan pesisir Kabupaten Subang adalah 333,57 $\mathrm{km}^{2}$ atau 16\% dari luas seluruh Kabupaten Subang.

Potensi Tambak

Potensi tambak Kabupaten Subang ini sangat besar, panjang pantai mencapai $68 \mathrm{~km}$ potensial untuk pengembangan usaha budidaya. Komoditas yang sangat cocok untuk dikembangkan adalah Rumput Laut (Euchema spp), Kakap (Lates carcarifer), Kerapu (Ephinephelus spp), Udang Windu (Penaeus monodon), Udang Putih (Penaeus merguensis), Bandeng (Channos channos) dan Kerangkerangan serta jenis ikan lainnya. Seiring dengan besarnya peluang usaha tambak, maka peluang usaha pembenihan (hatchery) pun sangat luas. Tahun 2011 di Kabupaten Subang memiliki potensi lahan budidaya tambak seluas kurang lebih 14.300 ha yang terletak di lima kecamatan yaitu Blanakan, Pamanukan, Pusakanagara, Sukasari dan Legonkulon. Produksi udang di
Subang tahun 2009 tercatat 3.143,50 ton, tahun 2010 sebanyak 2.004 ton, dan pada tahun 2011 produksi udang dari lahan budidaya tambak yang dimanfaatkan adalah sebesar 2106,72 ton .

Hasil Survey Parameter Fisika-Kimia Air

Hasil pengukuran parameter kualitas perairan pesisir Kabupaten Subang disajikan pada Tabel 5

Kecerahan (transparancy) menunjukkan seberapa jernih air disuatu perairan, sehingga kecerahan dapat mencerminkan jumlah plankton disuatu perairan. Kecerahan adalah gambaran kedalaman air yang dapat ditembus oleh cahaya matahari dan dapat dilihat oleh mata pada umumnya. Kecerahan air ditentukan oleh partikel-partikel tersuspensi seperti tanah liat, bahan organik dan mikroorganisme. Boyd (1982) menyatakan bahwa kecerahan akibat lumpur sekitar $30 \mathrm{~cm}$ dapat membatasi penetrasi cahaya sehingga tidak dapat menembus kedalaman air dan mengganggu pertumbuhan plankton. Batas kecerahan optimal untuk udang adalah antara 30$40 \mathrm{~cm}$ (Hardjowigeno, 2001). Kecerahan air

Tabel 4. Kecamatan Pesisir di Kabupaten Subang

\begin{tabular}{|c|c|c|}
\hline No. & Kecamatan & Luas $\left(\mathrm{km}^{2}\right)$ \\
\hline 1. & Blanakan & 85,81 \\
\hline 2 . & Pamanukan & 80,89 \\
\hline 3. & Legon Kulon & 98,47 \\
\hline 4 & Pusakanegara & 68,40 \\
\hline & Jumlah & 333,57 \\
\hline
\end{tabular}

Sumber: Monografi Kabupaten Subang, 2014 
Kualitas Air dan Komunitas Plankton Pada Tambak Pesisir

Kabupaten Subang Jawa Barat

Tabel 5. Kualitas Air di Lokasi Penelitian

\begin{tabular}{|l|c|c|c|c|c|c|}
\hline Parameter & St l & St 2 & St 3 & St 4 & St 5 & St 6 \\
\hline pH & 7,9 & 7,5 & 7,6 & 7,8 & 7,8 & 7,4 \\
\hline Suhu & 28 & 32 & 32 & 28 & 29 & 32 \\
\hline Kecerahan & 30 & 50 & 55 & 35 & 40 & 50 \\
\hline Salinitas & 30 & 38 & 38 & 30 & 30 & 35 \\
\hline TSS & 40 & 35 & 30 & 45 & 40 & 35 \\
\hline $\mathrm{DO}$ & 4,7 & 3,5 & 3 & 4,5 & 4 & 3 \\
\hline $\mathrm{NH}$ & 0,46 & 0,54 & 0,76 & 0,50 & 0,52 & 0,53 \\
\hline $\mathrm{COD}$ & 9,27 & 26,55 & 14,62 & 10,87 & 10,82 & 13,87 \\
\hline $\mathrm{BOD}$ & 3,71 & 5,85 & 5,55 & 4,35 & 4,33 & 10,62 \\
\hline $\mathrm{NO}_{3}$ & 20,33 & 22,1 & 21,66 & 20,33 & 20,77 & 21,77 \\
\hline $\mathrm{PO}_{4}$ & 0,03 & 0,24 & 0,24 & 0,05 & 0,03 & 0,28 \\
\hline $\mathrm{NO}_{2}$ & 0,010 & 0,075 & 0,052 & 0,019 & 0,035 & 0,073 \\
\hline
\end{tabular}

Sumber : Data primer, 2014

yang terukur di tambak Subang berkisar 30 - 55 $\mathrm{cm}$ (Gambar 2). Kecerahan tertinggi terdapat pada stasiun 3 sekitar $55 \mathrm{~cm}$ di Kecamatan Blanakan, hal ini karena lokasi tersebut tidak ada mangrove di tambak. Mangrove memerlukan substrat berlumpur untuk hidupnya sehingga pada kecerahan yang tinggi mangrove tidak dapat tumbuh dengan baik. Pohon mangrove baik daun, ranting maupun pohon maupun pohon yang gugur menjadi serasah membusuk yang dapat menyebabkan kekeruhan pada perairan. Sebaliknya kecerahan paling rendah adalah pada stasiun 1 sekitar $30 \mathrm{~cm}$ dimana terdapat tanaman mangrove tebal ditempat tambak.

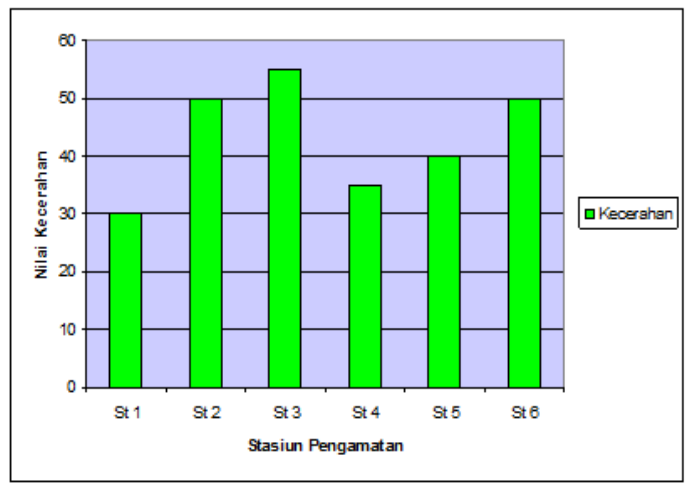

Gambar 2. Konsentrasi Kecerahan Perairan
Suhu air terendah hasil pengamatan tedapat pada St 1 sekitar 28 derajat celsius dan suhu air yang tertinggi terdapat pada St 2, St 3 dan St 6 yaitu sekitar 32 derajat Celsius. Suhu air yang terukur di tambak Subang masih dalam kisaran yang normal yaitu berkisar antara 28 $32^{\circ} \mathrm{C}$ Gambar 3. Adanya perbedaan suhu antar stasiun dikarenakan tanaman mangrove yang cukup tebal di St 1 sehingga suhu sekitar tambak rendah dibandingkan di St 2, St 3 dan St 6 yang tidak ada tanaman mangrovenya. Suhu juga dapat mempengaruhi penyebaran, komposisi, serta kelimpahan fitoplankton diperairan. Menurut Handayani (2009) suhu air merupakan

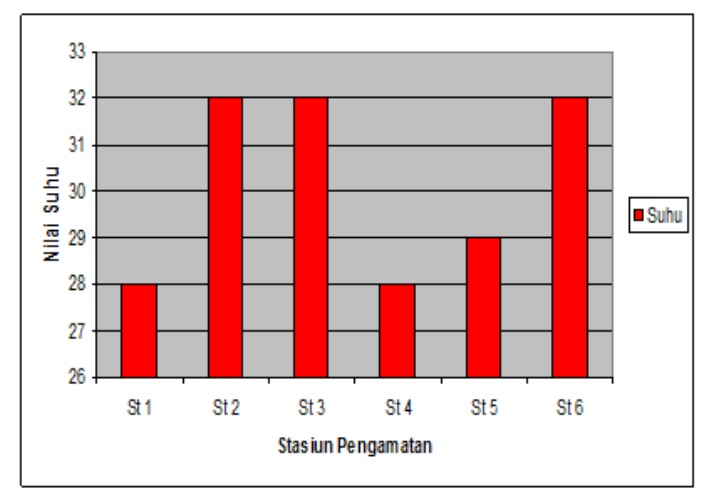

Gambar 3. Konsentrasi Suhu di Perairan 


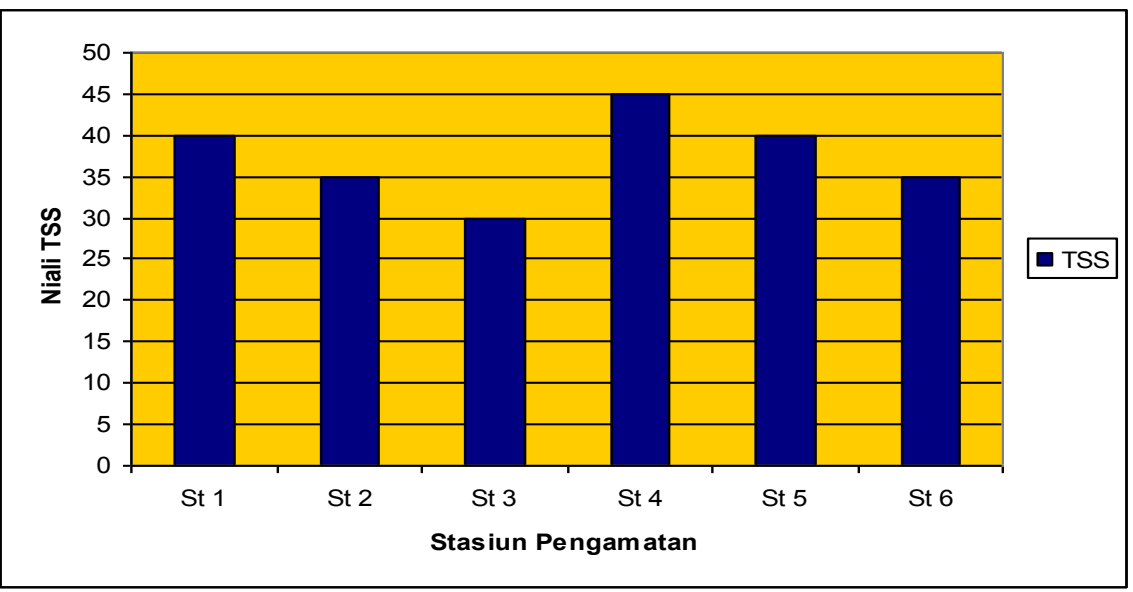

Gambar 4. Konsentrasi TSS di Perairan

salah satu faktor fisika penting yang banyak mempengaruhi kehidupan hewan dan tumbuhan air salah satunya adalah plankton.

Kandungan total padatan tersuspensi (TSS) yang terukur di tambak Subang yaitu sekitar 30 - 45 ppm (Gambar 4). Padatan tersuspensi (TSS) yang tertinggi terdapat pada St 4. Sekitar $45 \mathrm{ppm}$, masih termasuk kategori yang baik karena perairan yang mempunyai nilai kandungan padatan tersuspensi sebesar 300 - 400 ppm mutu perairan tersebut tergolong buruk (Allert, 1984).

Total padatan tersuspensi adalah padatan yang tersuspensi di dalam air berupa bahanbahan organik dan inorganik yang dapat disaring dengan kertas millipore berporipori $0,45 \mu \mathrm{m}$. Materi yang tersuspensi mempunyai dampak

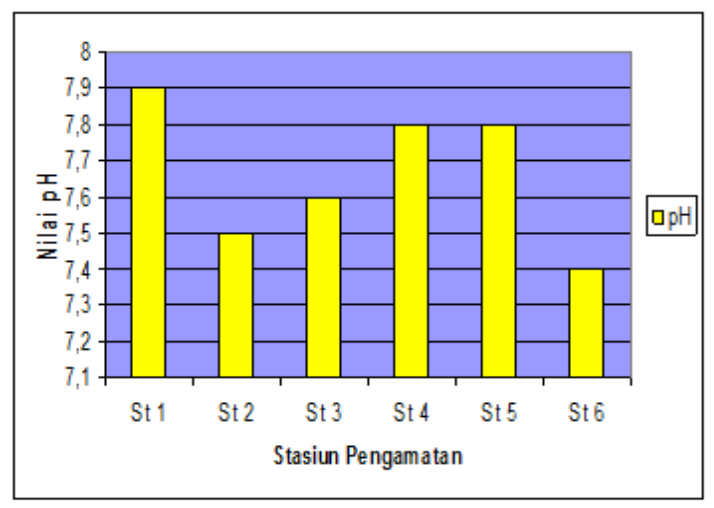

Gambar 5. Konsentrasi pH Perairan. buruk terhadap kualitas air karena mengurangi penetrasi matahari ke dalam badan air, kekeruhan air meningkat yang menyebabkan gangguan pertumbuhan bagi organisme produser.

Nilai $\mathrm{pH}$ di tambak Kabupaten Subang berkisar antara 7,4-7,9 (Gambar 5). Nilai pH tertinggi terdapat pada Stasiun-1 sekitar 7.9. Nil ai ini memenuhi syarat untuk budidaya udang. Air laut memiliki $\mathrm{pH}$ yang relatif stabil dan biasanya berkisar antara 7,5 - 8,4. Nilai $\mathrm{pH}$ suatu perairan dapat berubah jika perairan tersebut ternyata mengalami gangguan seperti pencemaran dan ketidakstabilan lingkungan perairan. Perubahan nilai $\mathrm{pH}$ perairan dapat dipengaruhi oleh beberapa faktor diantaranya adalah aktifitas fotosintesis, suhu serta buangan limbah.

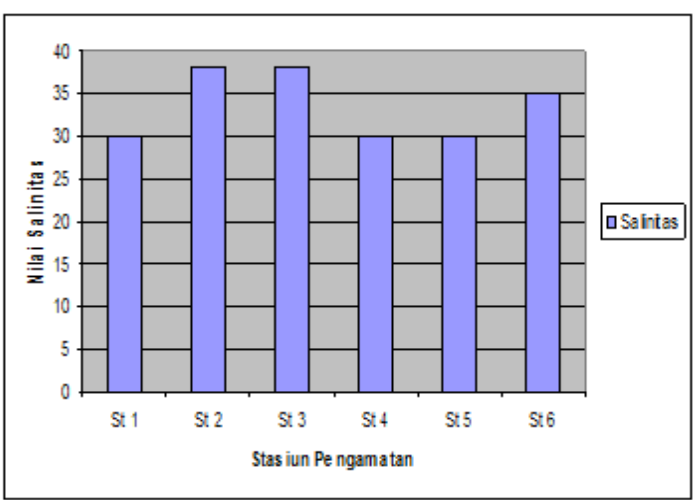

Gambar 6. Konsentrasi SalinitasPerairan. 


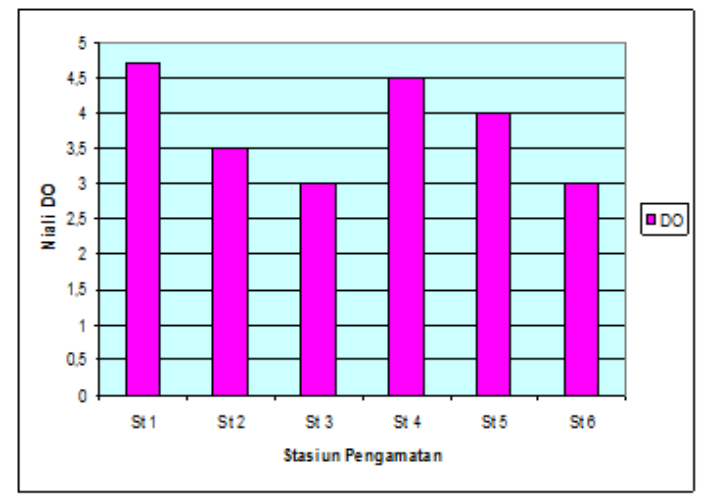

Gambar 7. Konsentrasi DO Perairan

Air untuk pengairan tambak udang dapat diperoleh langsung dari laut dengan salinitas antara 30-36\%. Udang windu mampu hidup pada kisaran salinitas antara $15-50 \%$, pada salinitas $<15 \%$ o udang dapat tumbuh dengan baik asalkan perubahan salinitas itu tidak terjadi secara mendadak. Walaupun udang mempunyai sifat euryhaline, kisaran salinitas yang baik untuk tambak udang adalah $10-35 \%$ dengan kisaran optimum 15 - 25\% (Poernomo,1992). Nilai salinitas di tambak Subang berkisar $30-38 \%$ o.

Oksigen terlarut merupakan salah satu parameter kimia air yang berperan pada kehidupan biota perairan. Penurunan okasigen terlarut dapat mengurangi efisiensi pengambilan oksigen bagi biota perairan sehingga menurunkan kemampuannya untuk hidup normal. Menurut Lung (1993), kelarutan oksigen minimum untuk mendukung kehidupan ikan adalah sekitar $4 \mathrm{ppm}$. Nilai oksigen terlarut di tambak Subang adalah berkisar antara 3,0-4,7 ppm. Nilai tersebut masih mendukung kehidupan biotaperairan yaitu minimum 4, 0 ppm. Yazwar (2008) menegaskan bahwa nilai oksigen terlarut diperairan sebaiknya berkisar anatara $6,3 \mathrm{mg} / \mathrm{l}$, Mangkin rendah nilai oksigen terlarut maka maikn tinggi tingkat pencemaran suatu ekosistem perairan tersebut. Plankton dapat hidup dengan baik pada konsentrasi lebih dari $3 \mathrm{mg} / \mathrm{l}$.

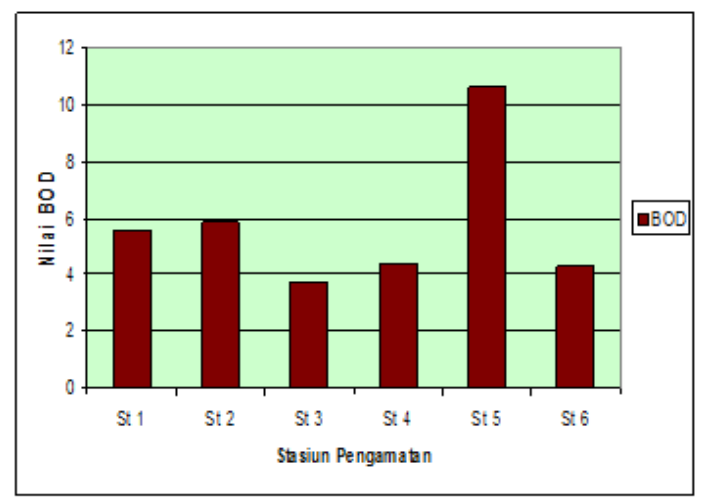

Gambar 8. Konsentrasi BOD Perairan

BOD merupakan parameter yang dapat digunakan untuk menggambarkan keberadaan bahan organik di perairan. Hal ini disebabkan BOD dapat menggambarkan jumlah bahan organik yang dapat diuraikan secara biologis, yaitu jumlah oksigen terlarut yang dibutuhkan oleh mikroorganisme untuk memecahkan atau mengoksidasi bahan-bahan organik menjadi karbondioksida dan air. Nilai BOD yang tinggi menunjukkan semakin besarnya bahan organik yang terdekomposisi menggunakan sejumlah oksigen di perairan. Adapun nilai BOD di tambak Subang berkisar antara 3,71 - 10,62 $\mathrm{mg} / \mathrm{l}$, dengan rata-rata $5,7 \mathrm{mg} / \mathrm{l}$. Berdasarkan baku mutu air, nilai BOD yang dipersyaratkan $20 \mathrm{mg} / \mathrm{l}$. Dengan demikian, disimpulkan bahwa tambak di Subang tidak tercemar oleh bahan organik mudah urai (BOD).

Parameter lain yang juga dapat digunakan sebagai penduga pencemaran limbah organik adalah COD. Nilai COD menggambarkan total oksigen yang dibutuhkan untuk mengoksidasi bahan organik secara kimiawi, baik yang dapat didegradasi secara biologi (biodegradable) maupun yang ternyata sukar didegradasi (non biodegradable) secara biologi atau terurai dalam suatu perairan menjadi produk akhir berupa karbon dioksida $\left(\mathrm{CO}_{2}\right)$ dan senyawa molekul air $\left(\mathrm{H}_{2} \mathrm{O}\right)$. 


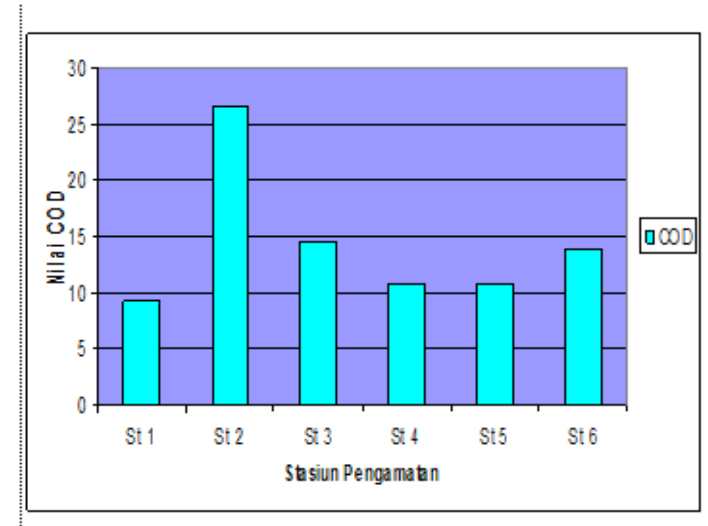

Gambar 9. Konsentrasi COD Perairan

Dari hasil analisis kualitas air tambak di Subang menunjukkan bahwa nilai COD perairan berkisar antara 9,27-26,55 mg/l, dengan nilai rata-rata 14,2 mg/l. Berdasa rkan baku mutu air yang mempersyaratkan nilai COD adalah 40 mg/l, maka tambak di Subang tidak tercemar oleh bahan organik sulit terurai Nilai COD menunjukkan jumlah total oksigen yang dibutuhkan untuk proses oksidasi yang berlangsung secara kimiawi. Dengan demikian maka umumnya nilai COD akan selalu lebih besar dibandingkan dengan nilai BOD5, karena nilai BOD5 terbatas hanya terhadap bahan organik yang bisa diuraikan secara biologis saja, sementara nilai COD menggambarkan kebutuhan oksigen untuk total oksidasi, baik terhadap senyawa yang dapat diuraikan secara biologis maupun terhadap senyawa yang tidak dapat diuraikan secara biologis (Baur,1 987 dalam Barus 2004).

Ammonia di perairan dapat berasal dari nitrogen organik dan nitrogen anorganik yang terdapat dalam tanah dan air berasal dari dekomposisi bahan organik oleh mikroba dan jamur. Selain itu, ammonia juga berasal dari denitrifikasi pada dekomposisi limbah oleh mikroba pada kondisi anaerob. Ammonia juga dapat berasal dari limbah domestik dan limbah industri. Hasil analisis kualitas air menunjukkan

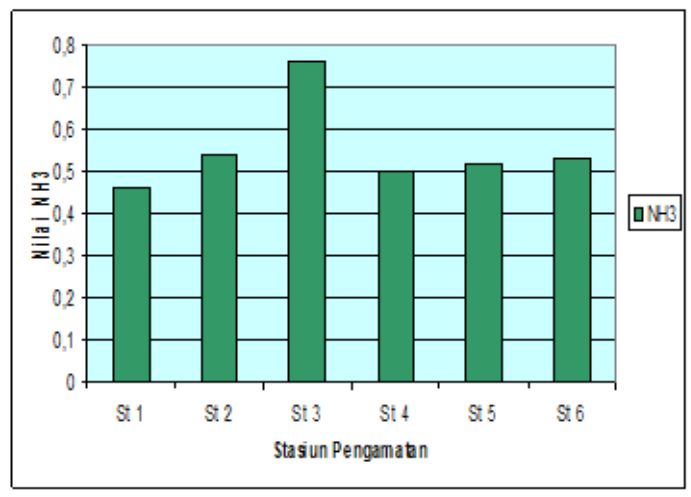

Gambar 10. Konsentrasi $\mathrm{NH}_{3}$ Perairan

kadar ammonia di tambak Subang berkisar antara 0,46-0,76 mg/l.. Berdasarkan baku mutu air mensyaratkan kandungan ammonia maksimal 0,3 mg/l. Dengan demikian dapat disimpulkan bahwa tambak di Subang diduga tercemar ammonia. (Gambar 10).

Hasil pengukuran kadar nitrat di tambak Subang berkisar antara 20,33-21,77 mg/l. Secara umum, kandungan nitrat di tambak Subang berada di atas baku mutu air, yang mensyaratkan kandungan nitrat untuk air baku maksimal 10 mg/l. Dengan demikian dapat disimpulkan bahwa tambak Subang diduga tercemar oleh senyawa nitrat.

Fosfat yang terdapat di perairan bersumber dari air buangan penduduk (limbah rumah tangga) berupa deterjen, residu hasil pertanian (pupuk), limbah industri, hancuran bahan organik dan mineral fosfat (Saeni, 1989). Umumnya kandungan fosfat dalam perairan alami sangat kecil dan tidak pernah melampaui $0,1 \mathrm{mg} / \mathrm{l}$, kecuali bila ada penambahan dari luar seperti dari sisa pakan ikan dan limbah pertanian. Hasil analisis kualitas air menunjukkan kadar fosfat di tambak Kabupaten Subang berkisar antara 0,03-0,28 mg/l (Gambar 12). Kandungan fosfat menggambarkan adanya dinamika di perairan tambak Kabupaten Subang, lokasi pengambilan contoh air. 


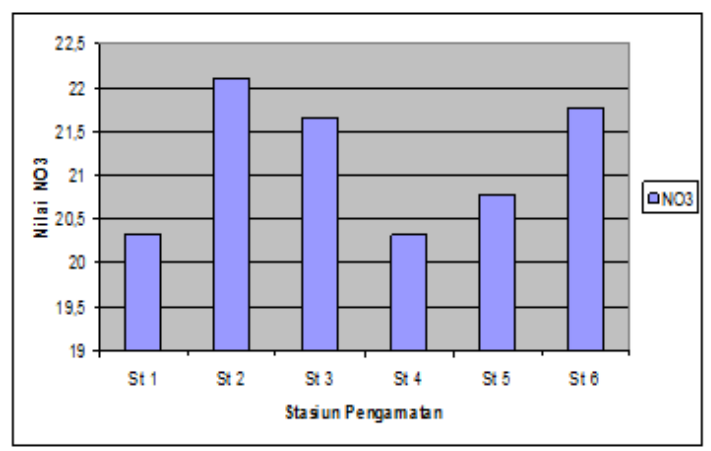

Gambar 11. Konsentrasi $\mathrm{NO}_{3}$ Perairan.

\section{Indeks Diversitas Plankton}

Komposisi plankton hasil penelitian dapat dilihat pada tabel 6. Tugiyono (2004) Metode pemantuan terhadap perubahan kualitas air salah satunya dapat dilakukan dengan menggunakan biota air (indikator biologi) selain dengan analisis parameter fisika-kimia air. Indikator biologi adalah spesies atau populasi hewan, tumbuhan, atau mikroorganisme, yang kehadiranya atau perkembangannya sebagai tanggapan atau respon terjadinya perubahan lingkungan dan mudah diamati setiap terjadi perubahan. Studi indeks diversitas organisme bentik, plankton dan penyebaran penutupan rumput laut banyak digunakan sebagai indikator biologi terhadap perubahan lingkungan perairan. Salah satu manfaat plankton adalah untuk mengetahui adanya pencemaran dengan mengetahui kemelimpahan dan keanekaragaman jenis plankton, misalnya skeletonema sp dan Brachionus sp populasinya akan melimpah pada perairan yang kaya akan bahan organik. Berdasarkan indeks keanekaragaman (H') plankton, perairan dapat di kelompokan kualitasnya sebagai berikut; jika nilai H'>3 berarti perairan bersih atau tidak tercemar, $3<\mathrm{H}$ ' $<1$,berarti perairan tercemar sedang atau ringan dan $H^{\prime}<1$, berarti perairan tercemar berat. Perubahan plankton sangat dipengaruhi oleh

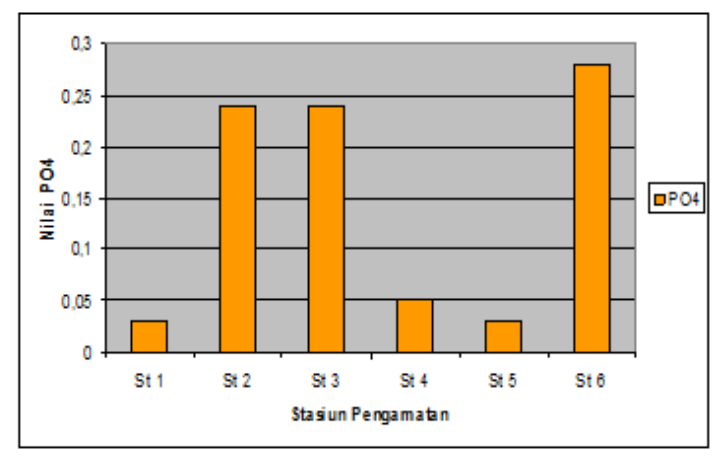

Gambar 12. Konsentrasi $\mathrm{PO}_{4}$ Perairan

masuknya berbagai faktor kimia dan fisika air yang masuk dari daerah sekitarnya, seperti sekitar mulut sungai besar, plankton biasanya sangat subur karena di sini mempunyai kandungan nutrisi yang kaya dan kolom air yang stabil.

Dalam bidang perikanan, plankton berperan penting sebagai sumber nutrisi perairan. Adanya proses pasang surut di sekitar perairan Subang berdampak pada kondisi fisika kimia perairan yang relatif berbeda di setiap saat sehingga mempengarui komposisi jenis plankton sebagai sumber pakan alami hewan budidaya. Fungsi fitoplankton adalah sebagai produsen, penyedia oksigen dalam perairan, indikator pencemaran dan lain-lain.. Fitoplankton dapat melakukan aktivitas hidupnya sendiri dengan memanfaatkan cahaya matahari karena adanya kandungan klorofil dalam selnya, adapun peran zooplankton sebagai konsumen primer. Peran plankton lainnya adalah sebagai indikator kesuburan perairan berdasarkan perhitungan kelimpahan plankton. Keberadaan fitoplankton dan zooplankton di kawasan tambak air payau sepanjang tahun secara kualitatif dan kuantitatif selalu berubah-ubah karena pengaruh kadar salinitas dan faktor lingkungan lain yang selalu berubah; misal adanya beban masukan ke dalam perairan tambak, akan memperkaya nutrisi yang mendukung pertumbuhan fitoplankton. 
Hasil analisis komunitas plankton pada 6 (enam) stasiun pengambilan contoh di tambak Subang mendapatkan data plankton secara keseluruhan berjumlah 13 jenis, terdiri dari 10 jenis fitoplankton dan 3 jenis zooplankton. Pada masing-masing stasiun menunjukkan bahwa jumlah taksa berkisar antara 6 hingga 13 jenis, dengan kelimpahan total berkisar antara 400 hingga 2020 individu/liter. Hasil penghitungan indeks diversitas menunjukkan bahwa tingkat keanekaragaman komunitas plankton pada tambak yang bermangrove tebal tergolong rendah yakni dari 1,2299 sampai 1,2731. Sedangkan pada tambak yang mangrovenya tipis atau sedikit tergolong sangat rendah yakni dari 0,3509 sampai 0,7374. Fitoplankton yang mendominasi adalah divisi Chrysophyta.

Hal ini terkait dengan hubungan tingkatan tropik di perairan tersebut, dimana krustacea sebagai konsumen pertama yang memiliki kemampuan memecah komponen silikat pada Chrysophyta. Kelimpahan jenis plankton berbanding terbalik dengan keanekaragamannya (Odum, 1993) disebabkan adanya kondisi pasang surut yang membawa banyak campuran bahan organik dari perairan laut maupun perairan tawar sehingga dapat digunakan sebagai sumber bahan nutrisi bagi plankton, dan hal ini juga terkait

Tabel 6. Komposisi Plankton

\begin{tabular}{|c|c|c|c|c|c|c|}
\hline Fitoplankton & St 1 & St 2 & St 3 & St 4 & St 5 & St 6 \\
\hline \multicolumn{7}{|l|}{ A. Chrysophyta } \\
\hline Biddulphia Sinensis & 160 & 20 & 20 & 40 & 40 & \\
\hline Chaetoceros Sp & 20 & & & 40 & & 20 \\
\hline Cilindrotheca Closterium & & & & & & 20 \\
\hline Closterium Sp & & 40 & & & & \\
\hline Coscinodiscus Discus & & & 20 & & & \\
\hline Ditylum brightwellii & 20 & & & 20 & & 20 \\
\hline Melosira nummuloides & 40 & & & 40 & & 40 \\
\hline Navicula Sp & 40 & & & & & \\
\hline Nitachia seriata & 20 & & & 40 & 20 & \\
\hline \multicolumn{7}{|l|}{ Rhizosolenia Alata } \\
\hline Skeletonema costatum & 1360 & 260 & 280 & 1320 & 300 & 1100 \\
\hline Thalasionema nitzschioides & 20 & & & & & \\
\hline \multicolumn{7}{|l|}{ B. Cyanophyta } \\
\hline Oscillatoria Sp & 20 & & & & & \\
\hline \multicolumn{7}{|l|}{ C. Chlorophyta } \\
\hline Characium Longicens & 20 & & & 20 & & \\
\hline Genicularia Elegams & & & & 40 & & \\
\hline Microspora Stagnorum & & 20 & & 40 & & \\
\hline \multicolumn{7}{|l|}{ D. Dinoflagellata } \\
\hline Ceratium tripos & & 100 & 20 & 200 & 120 & 40 \\
\hline Favella ehren bergii & 20 & 40 & 20 & & 40 & 20 \\
\hline \multicolumn{7}{|l|}{ E. Zooplankton } \\
\hline Calamus Sp & 240 & 80 & 20 & 40 & 40 & 20 \\
\hline Clausocalamus pergens & 40 & & 20 & & & 20 \\
\hline Mecynocera claus & & 40 & & 40 & & 20 \\
\hline Jumlah Total & 2020 & 600 & 400 & 1880 & 560 & 1320 \\
\hline
\end{tabular}


dengan kesuburan perairan tersebut. Plankton di daerah estuaria memiliki keanekaragaman jenis yang sedikit karena kondisi fisika dan kimia perairan yang sering sekali berubah-ubah (Odum, 1993). Chrysophyta sering mendominasi fitoplankton di daerah estuaria, sedangkan zooplankton banyak didominasi oleh jenis krustacea (Nybakken, 1988).Fitoplankton merupakan indikator biologi untuk mengevaluasi kualitas dan tingkat kesuburan suatu perairan (Makmur dkk, 2011). Keragaman jenis plankton yang terdapat di perairan hutan mangrove Blanakan dan Cilacap termasuk miskin atau kurang karena nilai indeks keragaman (H') kurang dari dua (Blanakan 1,242; Cilacap 1,841) (Heriyanto 2012).

Beberapa faktor yang menentukan perkembangan hidup fitoplankton kekeruhan, proses fotosintesis, serta penyediaan atau tersedianya unsur hara yang memadai (Akrimi dan Subroto 2002). Komunitas plankton pada seluruh tambak di kabupaten Maros pada musim hujan dalam kondisi tidak stabil. Sedangkan pada musim kemarau nilai indeks keragaman antara 01,842 dengan rata-rata $0,756 \pm 0,517$, hal ini menunjukkan bahwa indeks keragaman pada musim kemarau juga tidak stabil karena indeks masih di bawah $\mathrm{H}^{\prime}<1$. Namun indeks keragaman pada musim kemarau lebih baik dibandingkan dengan musim hujan, dapat dilihat pada nilai indeks rata-rata kedua musim, musim kemarau nilai lebih tinggi (Fahrur dkk 2012).
Terdapat keterkaitan antara faktor fisikakimia atau pengaruhnya terhadap komunitas zooplankton dan ikan. Terlihat ada hubungan antar parameter, yaitu apabila kedalaman meningkat, maka ada kecenderungan $\mathrm{pH}$ akan turun, kecerahan rendah, suhu rendah, dan klorofil-a juga rendah. Permukaan air sangat mempengaruhi variasi dari masing-masing parameter mulai dari aspek kedalaman/ water level (Tania dkk. 2014 ). parameter fisika-kimia air yang mempunyai hubungan kuat terhadap indeks diversitas selain salinitas adalah nitrogen sebagai amonia dan sebagai nitrat. Pentingnya nilai nitrogen baik dalam bentuk amonia maupun nitrat dalam hubungan dengan nilai diversitas jenis plankton dikarenakan keberadaan nitrogen dalam perairan diduga berasal dari sisa pakan/pellet udang maupun ikan yang disebut sebagai sumber nitrogen organik. Sumber utama nitrogen adalah protein yang terkandung dalam pakan atau pellet udang maupun ikan yang terbuang keperairan melalui saluran pembuang tambak maupun keramba apung. Disamping itu sumber nitrogen juga dapat berasal dari limbah atau buangan yang mengandung senyawa protein organik lainya seperti bangkai biota laut maupun senyawa anorganik seperti pupuk nitogen (Urea, ZA dan lainnya) yang banyak digunakan dalam pertanian maupun pertambakan (Tugiyono 2004). Disamping itu juga diketahui unsur Nitrogen terdapat berlimpah bahi di peraiaran maupun difusi dari udara.

Tabel 7. Rangkuman hasil analisis sampel plankton

\begin{tabular}{|c|c|c|c|c|c|}
\hline Stasiun & $\begin{array}{c}\text { Kelimpahan } \\
\text { Total(Sel/Liter) }\end{array}$ & $\begin{array}{c}\text { Jumlah } \\
\text { Taksa }\end{array}$ & $\begin{array}{c}\text { Indeks } \\
\text { Diversitas }\end{array}$ & $\begin{array}{c}\text { Tingkat } \\
\text { Diversitas }\end{array}$ & $\begin{array}{c}\text { Kriteria } \\
\text { kualitas air }\end{array}$ \\
\hline I & 2020 & 13 & 1,2731 & Rendah & tercemar \\
\hline II & 600 & 8 & 0,7374 & Sangat rendah & Tercemar berat \\
\hline III & 400 & 7 & 0,4987 & Sangat rendah & Tercemar berat \\
\hline IV & 1880 & 12 & 1,2386 & Rendah & Tercemar \\
\hline V & 560 & 6 & 1,2299 & Rendah & Tercemar \\
\hline VI & 1320 & 10 & 0,3509 & Sangat rendah & Tercemar berat \\
\hline
\end{tabular}

Sumber : Data primer, 2014 
Holt dan Miller (2010) menyatakan bahwa bioindikator dapat digunakan untuk melihat pengaruh dari polutan terhadap komponen biotik, dimana hal tersebut tidak dapat dilakukan dengan pengukuran fisika dan kimiawi. Kondisi lingkungan suatu perairan dapat berpengaruh terhadap komposisi jenis, kelimpahan dan distribusi plankton yang terdapat didalamnya. Dominasi fitoplankton pada tambak lebih dikendalikan oleh pengelolaan air melalui pergantian air sebnayak 20-30\% dengan menggunakan sistem flow trough (mengalir; pembuangan dan pengisian air dilakukan bersamaan), dan penyiponan tambak setelah umur 70 hari. Komunitas fitoplankton yang dapat ditemukan dalam perairan berasal dari kelas Chlorophyta (green algae), Cyanophyta (bluegreen algae), Chrysophyta (Diatom), Euglonophyta dan Pyrrophyta Dynoflagellata) ( Budiardi dkk 2007).

Tambak silvofishery merupakan kegiatan terpadu antara budidaya perikanan dengan pelestarian dan penanaman hutan mangrove (Nuryanto, 2003). Jenis tambak ini memiliki kekhasan tersendiri. Di hutan mangrove, konsentrasi pertumbuhan plankton yang juga merupakan produsen primer zat organik kawasan perairan ini lebih rendah dibandingkan dengan perairan terbuka seperti lautan (Mulyadi, 1985 dalam heriyanto 2010). Plankton merupakan kelompok organisme yang hidup melayanglayang di dalam air dan memiliki daya renang yang sangat lemah. Kelimpahan dan keragaman jenis plankton dipengaruhi oleh kualitas fisik maupun kimia perairan berupa sedimentasi, fluktuasi ketinggian air, unsur hara, logam berat, temperatur, pH, dan kandungan oksigen (James, 1979 dalam heriyanto). Kelimpahan plankton juga ditentukan seberapa banyak biota yang memanfaatkan plankon sebagai makanan utama. karena perairan tambak dipengaruhi oleh pasang surut air laut yang berguna sebagai sumber pengisian air tambak tersebut, selain itu keberadaan vegetasi mangrove juga dapat mempengaruhi tingkat produktiftas tambak. Hal inilah yang membedakan silvofishery dengan jenis tambak budidaya perairan lainnya. Fungsi umum dari tambak silvofishery adalah sebagai salah satu solusi dalam meminimalisir perusakan dan eksploitasi hutan mangrove diwilayah ekosistem peraian dengan sistem silvofishery. Secara tidak langsung luruhan daun mangrove juga berguna sebagai penyedia unsur hara ekosistem perairan tambak, karena luruhan daunnya dapat terdekomposisi oleh detritus aquatic yang memiliki peranan penting dalam rantai makanan.

Pentingnya kawasan mangrove bukan hanya sebagai sumber daya hutan tetapi juga dijadikan sebagai kawasan sumber makanan utama bagi organisme air dalam bentuk bahan organik (detritus) yang dihasilkan dari dekomposisi serasah mangrove ataupun sebagai tempat pemijahan bagi hewan-hewan akuatik (Nontji, 2002). Adapun kerapatan vegetasi mangrove disetiap tambak silvofishery di Subang berbeda-beda, sehingga dapat mempengaruhi tingkat produktifitas setiap tambak. Terkait dengan peranan plankton sebagai sumber pakan alami perairan, menurut Raymont (1963) dalam Kamali (2004) apabila kelimpahan suatu plankton di suatu perairan tinggi, maka perairan tersebut memiliki produktifitas yang tinggi pula. Faktor penunjang pertumbuhan fitoplankton sangat kompleks dan saling berinteraksi antara faktor fisika-kimia perairan seperti intensitas cahaya, oksigen terlarut, stratifikasi suhu, dan ketersediaan unsur hara nitrogen dan fosfor, sedangkan aspek biologi adalah adanya aktivitas pemangsaan oleh hewan, mortalitas alami, dan 
dekomposisi (Goldman dan Horne, 1983).

Keberadaan plankton diperairan dapat dijadikan sebagai salah satu indikator suatu perairan karena sangat dipengaruhi oleh kualitas air. Fitoplankton merupakan indikator biologi untuk mengevaluasi kualitas dan tingkat kesuburan suatu perairan. Plankton merupakan hewan biotik yang menghuni air, fungsi dan manfaatnya sangat penting di perairan.

Kesuburan perairan berdasarkan kelimpahan plankton dibagi menjadi 3 (tiga) macam, Basmi (1987) dalam Indryani (2005), yaitu :

1. Eutrofik, kelimpahan plankton $>15000$ ind $/ 1$ dengan ciri-ciri perairan memiliki nilai kecerahan 0,2 meter, perairan berwarna hijau karena kepadatan plankton tinggi dan semakin dalam perairan maka semakin berkurang kandungan oksigen.

2. Mesotrofik, kelimpahan plankton 200015000 ind/1 merupakan perairan peralihan antara kedua sifat eutrofik dan oligotrofik.

3. Oligotrofik, kelimpahan plankton $<2000$ ind/l dengan ciri-ciri perairan cenderung kandungan nutrisi rendah dan air jernih.

Pengelolaan tambak secara tradisional dengan menggunakan plankton sebagai pakan alami ikan dan udang dapat memberikan kontribusi yang signifikan dalam keberhasilan usaha budidaya ditambak. Plankton khususnya fitoplankton selain sebagai nutrien untuk ikan dan udang juga sangat penting dalam memperbaiki kualitas air dan menjaga keseimbangan lingkungan serta dapat membuang senyawa - senyawa dalam air yang dapat menimbulkan racun terhadap ikan dan udang yang dibudidayakan. (Pirzan \& Pong - masak, 2008 )

\section{Kesimpulan Dan Saran}

Kesimpulan

1. Parameter kualitas air suhu, salinitas, $\mathrm{pH}$, kecerahan, TSS, $\mathrm{NO}_{2}, \mathrm{NO}_{3}, \mathrm{PO}_{4}, \mathrm{DO}, \mathrm{BOD}$ dan COD nilainya di semua stasiun berada dalam kisaran nilai baku mutunya masingmasing. Sedangkan parameter $\mathrm{NH}_{3}$ dan $\mathrm{NO}_{3}$ di semua stasiun telah melebihi nilai baku mutunya masing masing, ini berarti perairan tercemnar gas amoniak.

2. Komunitas plankton pada 6 (enam) stasiun pengambilan contoh di tambak Subang mendapatkan data plankton secara keseluruhan berjumlah 13 jenis , terdiri dari 10 jenis fitoplankton dan 3 jenis zooplankton.

3. Pada masing-masing stasiun menunjukkan bahwa jumlah taksa berkisar antara 6 hingga 13 jenis, dengan kelimpahan total berkisar antara 400 hingga 2020 individu/liter.

4. Hasil penghitungan indeks diversitas menunjukkan bahwa tingkat keanekaragaman komunitas plankton pada tambak yang bermangrove secara keseluruhan tergolong rendah yakni dari 1,2299 sampai 1,2731. Sedangkan pada tambak yang tidak bermangrove secara keseluruhan tergolong sangat rendah yakni dari 0,3509 sampai 0,7374. dan Fitoplankton yang mendominasi adalah divisi Chrysophyta.

Saran

Untuk meningkatkan keanekaragaman plankton di tambak subang sebaiknya tambak menggunakan pola silvofishery, dengan tetap mengedapankan kegiatan yang berhubungan dengan pelestarian dan konservasi. 


\section{Daftar Pustaka}

Akrimi, Subroto G. 2000. Tehnik pengamatan kualitas air dan plankton di reservat danau Arang Arang Jambi. Buletin Tehnik Pertanian volume 7 nomor 2, 2002

Barus, T.A. 2004. Faktor-Faktor Lingktjngan Abiotik Dan Keanekaragaman Plankton Sebagai Indikator Kualitas Perairan Danau Toba. Manusia dan Lingkungan, Vol. XI, No. 2, Juli 2004, hal. 64-72 Pusat Studi Lingkungan Hidup, Universitas Gadjah Moda

Bengen, D.G. 2000. Sinopsis Teknik Pengambilan Contoh dan Analisis Biofisik Sumberdaya Pesisir. Pusat Kajian Sumberdaya Pesisir dan Lautan (PKSPL).IPB

Boyd, C.E. 1982. Water Quality Management For Pond Fish Culture. Elsevier Scienctific Publishing Company. Alabama. USA.318 Pages.

Goldman, C. R. and A. J. Horne. 1983. Limnology. McGraw Hill International Book Company. Tokyo. 464 p.

Handayani. D. 2009. Kelimpahan dan Keanekaragaman Plankton di Perairan Pasang Surut Tambak Blanakan, Subang. Skripsi, Jurusan Biologi. UIN Syarif Hidayatullah: Jakarta.

Hardjowigeno, S.W. 2001. Kesesuaian Lahan dan Perencanaan Tata Guna Tanah. Fakultas Pertanian. IPB.

Heriyanto NM. 2010. Keragaman Plankton dan Kualitas Perairan di Hutan MangroveBuletin Plasma Nutfah Vol.18 No.1 Th.2012

Holt EA dan Miller SW. 2010. Bioindicators: Using Organisms to MeasureEnvironmental Impacts. Nature Education Knowledge 3(10):8.

Indryani, M. 2005. Struktur Komunitas Diatom dan Dinoflagelata Pada Beberapa Daerah Budidaya di Teluk Hurun, Lampung. Skripsi: Program Studi Biologi. Universitas Negeri Jakarta. Jakarta

Kamali, D. I. 2004. Kelimpahan Fitoplankton pada Keramba Jaring Apung di Teluk Hurun, Lampung. Skripsi: Program
Studi Manajemen Sumber Daya Perairan. Institut Pertanian Bogor.

Lung, W.S. 1993. Water Quality Modelling; Application to Estuaria. Vol II CRC Press. Florida.

Makmur, rachmansyah, Mat fahrur. 2010. Hubungan antara kualityas air dan plankton di tambak Kabupaten Tanjung Jabung barat provinsi Jambi. Proseding forum inovasi teknologi akuakultur 2011

Mat Fahrur, Makmur, Rachmansyah. 2012.DinamikaKualitas Air Dan Hubungan Kelimpahan Plankton Dengan Kualitas Air Di Tambak Kecamatan Bontoa, Kabupaten Maros. Prosiding Indoaqua - Forum Inovasi Teknologi Akuakultur 2012

Naamin, N. 1991. Penggunaan Huan Mangrove untuk Budidaya Tambak Keuntungan dan Kerugian. Dalam Prosiding Seminar IV Ekosistem Hutan Mangrove MAB Indonesia LIPI. Bandar Lampung.

Nontji, A. 2002. Laut Nusantara. Djambatan, Jakarta.

Nuryanto, A. 2003. Silvofishery (Mina Hutan): Pendekatan Pemanfaatan Hutan Mangrove Secara Lestari. Makalah Pengantar Falsafah Sains. Program Pasca Sarjana / S3. Institut Pertanian Bogor. Bogor

Nybakken,j. W. (1988). Biologi Laut. SuatuPendekatan Ekologis. Jakarta : Gramedia.

Odum, E.P. 1993. Dasar-dasar Ekologi. Edisi ketiga. Penerjemah: Samingan, $\mathrm{T}$. Gadjah Mada University Press. Yogyakarta.

Pirzan,A.M. Pong Masak P.R. 2008. Hubungan produktifitas tambak dengan keberagaman Fitoplankton di Sulawesi Selatan. J. Ris. Akuakultur,2(2)

Poole, R.W. 1974. An Introduction to Quantitative Ecology. Mc. Graw Hill Kogakusha, Ltd. Tokyo. 325 Pages

Sugianto. 1994. Ekologi Kuantitatif Metode Analisis Populasi dan Komunitas. Airlangga University - Press. Surabaya

Tania S A , Saptami UE. 2014. Analisis Hubungan Kualitas Air Terhadap Komunitas Zooplankton dan Ikan di 
Kualitas Air dan Komunitas Plankton Pada Tambak Pesisir

Kabupaten Subang Jawa Barat

Danau Hanjalutung. Jurnal Ilmu Hewani

Tropika Vol 3. No. 2. Desember 2014

T. Budiardi, I. Widyaya dan D. Wahjuningrum

2007. Hubungan Komunitas

Fitoplankton Dengan Produktivitas

Udang Vaname (Litopenaeus

Vannamei) Di Tambak Biocrete.

Jurnal Akuakultur Indonesia, 6(2): 119-

125 